\title{
COMPARATIVE BIOLOGICAL EVALUATION OF FOUR ENDOPHYTIC FUNGI ISOLATED FROM NIGELLA SATIVA SEEDS
}

Ahmed M. Metwaly*1, Mohamed A. Ashour ${ }^{1}$, Shabana Khan ${ }^{2}$, Guoyi Ma ${ }^{2}$, Hazem A. Kadry ${ }^{1}$, Atef A. El-Hela ${ }^{1}$, Abd-Elsalam I. Mohammad ${ }^{1}$, Stephen J. Cutler ${ }^{3}$ and Samir A. Ross ${ }^{2}$

${ }^{1}$ Department of Pharmacognosy, Faculty of Pharmacy, Al-Azhar University, Cairo, Egypt

${ }^{2}$ Department of Biomolecular Science, National Center for Natural Products Research, University of Mississippi, Oxford, MS 38677, USA

${ }^{3}$ Department of Medicinal Chemistry, School of Pharmacy, the University of Mississippi, Oxford, MS 38677, USA

*Corresponding authors: ametwaly@azhar.edu.eg

\begin{abstract}
:
In this study, a total of four endophytic fungi have been isolated from Nigella sativa (Ranunculaceae) seeds growing in Egypt. The isolated fungi were identified morphologically and microscopically up to species to be; Alternaria pluriseptata, Aspergillus tubingensis, Aspergillus parasiticus and Eurotium pseudoglaucus. The extracts of the all identified fungi were screened biologically for antileukemic, cytotoxic, antimalarial, antileishmanial, antimicrobial, antioxidant and antiinflammatory activities as well as for cannabinoid and opioid receptor binding affinities. All the examined fungal extracts showed good antileukemic activities with Ic $_{50}$ values ranging from 0.025 to $0.8 \mu \mathrm{g} / \mathrm{ml}$, while two of them showed cytotoxic activities against Pig kidney epithelial (LLC-PK1) cells. Two fungal extracts exhibited antimalarial activities, three showed antioxidant activities and two exhibited antiinflammatory activities
\end{abstract}

Keywords: endophytic fungi, antileukemic, cytotoxic, Nigella sativa, Aspergillus tubingensis. 


\section{Introduction}

Endophytic fungi are defined as fungi that inhabit inside healthy plant tissues in their a part or whole life cycle without causing any apparent harm (Petrini, 1991; Schulz et al., 1999). The literal translation of the word endophyte is originated from the Greek words ,endon meaning inside and phyton meaning plant (Jalgaonwala et al., 2017). Researchers have shown that endophytic fungi can protect their host plants from several living dangers such as pathogens through secreting antimicrobial compounds and increasing plant resistance to infection (Gao et al., 2010). In addition, it was found that some endophytic fungi can give their host plant the ability to accommodate different types of stresses as drought (Elmi and West, 1995), excess salt (Waller et al., 2005) and heat (Márquez et al., 2007). Endophytic fungi can be considered as a source of chemically novel bioactive secondary metabolites belonging to different chemical classes (Tenguria et al., 2011). Several bioactive metabolites have been characterized from endophytic fungi over last years, and those isolated compounds found to be belong to diverse structural groups such as; alkaloids (Metwaly et al., 2015), isochromenes,(Metwaly, A.M. et al., 2014b) benzopyranones (Metwaly, A. et al., 2014), a-pyrones (Metwaly, A.M. et al., 2014a; Metwaly et al., 2017), steroids (Hussain et al., 2009), terpenoids (Bilal et al., 2018), peptides (Tawfike et al., 2018), polyketones (Zheng et al., 2018), quinones (Stierle and Stierle, 2015), phenolics(Das et al., 2018), xanthones (Li et al., 2016), isocoumarines (Orfali et al., 2015), perylene derivatives (Chagas et al., 2016), furandiones ( $\mathrm{Li}$ et al., 2015) and butenolide derivatives (Guo et al., 2016) . Recently, there has been a noticeable interest of researches on endophytic fungi producing important metabolites with a great diversity of biological activities such as antileukemic (Metwaly, A.M. et al., 2014a), anti-cancer (Chandra, 2012), antimicrobial(Kumar and Kaushik, 2012), anti-inflammatory (Deshmukh et al., 2009), antimalarial (Wiyakrutta et al., 2004), antileishmanial (Metwaly et al., 2013) and antioxidant (Huang et al., 2007).

\section{Materials and Methods}

\subsection{Fungal material}

\subsubsection{Isolation of endophytic fungi}

The fungi were isolated from surface sterilized fresh seeds of an apparently healthy Nigella sativa collected from botanical garden of faculty of pharmacy, Al-Azhar University, Cairo, Egypt. The seeds were rinsed with water and followed by surface sterilization in $70 \% \mathrm{EtOH}$ for $1 \mathrm{~min}$, rinsed again with sterilized water, then cut into two halves and deposited in a petri dish containing PDA medium (200 g potato, $20 \mathrm{~g}$ glucose, and $15 \mathrm{~g}$ agar in $1 \mathrm{~L}$ distilled water, supplemented with $100 \mathrm{mg} / \mathrm{L}$ chloramphenicol) and cultivated at $28^{\circ} \mathrm{C}$ for 3 days. The hypha tips were observed and transferred to new PDA plates and subcultured until pure culture was obtained.

\subsubsection{Identification of endophytic fungi}

The fungi were identified by the Regional Center for Mycology and Biotechnology, Cairo, Egypt. Pure colony of each fungal isolate was inoculated on different medium (potato-dextrose agar, Czapek's agar, Czapek's yeast extract agar 
(CYA) and malt extract agar) and incubated for 1-7 days. Cultural features for each fungal isolate in addition to microscopic examination of reproductive structure were recorded. identification was based on current universal keys (Fisher and Cook, 1998; Hoog et al., 2000) and on the data base identification program of the Regional Center for Mycology and Biotechnology (RCMB) for fungi using an Image Analysis System.

\subsubsection{Mass cultivation}

Each endophytic fungus was grown on PDA at $28{ }^{\circ} \mathrm{C}$ for 5 days. Ten pieces $\left(0.5 \times 0.5 \mathrm{~cm}^{2}\right)$ of mycelial agar plugs were inoculated into ten $1000 \mathrm{~mL}$ Erlenmeyer flasks containing sterilized (100 g Asian rice and $100 \mathrm{ml}$ distilled water). The flasks were incubated under static conditions at room temperature for 40 days.

\subsection{Extraction}

Each fungus was extracted by adding $1 \mathrm{~L}$ EtOAc (twice) to each flask and homogenized. The homogenized suspensions were collected, filtrated, concentrated under vacuum and prepared for biological assay.

\subsection{Antileukemic assay}

Human acute leukemia HL60 cells and human chronic leukemia K562 cells were purchased from American Type Culture Collection, Rockville MD, USA. Both cell lines were grown in suspension culture at $37{ }^{\circ} \mathrm{C}$ in RPMI-1640 medium supplemented with $10 \%$ non-dialysed fetal bovine serum (FBS), $2 \mathrm{mM}$ L-glutamine, $100 \mathrm{units} / \mathrm{mL}$ of penicillin and $10 \mu \mathrm{g} / \mathrm{mL}$ of streptomycin. For the cell growth inhibition assay, HL60 and K562 cells were seeded at 1 x 10 ${ }^{5}$ cells/well in Costar 24-well plates. Cells could grow undisturbed for $24 \mathrm{~h}$ before addition of test samples. After $48 \mathrm{~h}$ incubation with samples at $37^{\circ} \mathrm{C}$, viable cell counts were made by using the trypan blue exclusion method to assess cell viability (Roper and Drewinko, 1976).

\subsection{Cytotoxicity Assay}

Cytotoxicity was determined against HepG2 (human hepatocarcinoma), Vero (African green monkey kidney fibroblasts) and LLC-PK 1 (pig kidney epithelial) cells as described earlier (Mustafa et al., 2004). Doxorubicin was used as a positive control.

\subsection{Antimalarial assay}

Crude extracts were tested for activity against chloroquine-sensitive (D6, Sierraleon) and -resistant (W2, Indo-china) strains of Plasmodium falciparum using previously reported method (Bharate et al., 2007). The anti-malarial screen tests samples for their ability to inhibit the chloroquine-sensitive (D6) and/or chloroquineresistant (W2) Plasmodium falciparum protozoan. Crude extracts are initially tested against the D6 P. falciparum strain.

\section{Primary Screen;}

at $15867 \mathrm{ng} / \mathrm{mL}$ in duplicate, and percent inhibitions (\% inh.) are calculated relative to negative and positive controls. Extracts showing $\geq 50 \%$ inhibition proceed to the Secondary Assay.

\section{Secondary Assay;}

In the secondary antimalarial assay, samples dissolved to $20 \mathrm{mg} / \mathrm{mL}$ (crude extracts and some column fractions) are tested at 47600, 15867, and 5289ng/mL and 
$\mathrm{IC}_{50} \mathrm{~s}$ (test concentration in $\mathrm{ng} / \mathrm{mL}$ that affords $50 \%$ inhibition of the protozoan relative to negative and positive controls) vs. both the D6 and W2 strains are reported. Samples dissolved to $2 \mathrm{mg} / \mathrm{mL}$ are tested at 4760,1587 , and $529 \mathrm{ng} / \mathrm{mL}$ and $\mathrm{IC}_{50} \mathrm{~s}$ vs. both the D6 and W2 strains are reported. In addition to the $P$. falciparum strains, samples are tested in the VERO mammalian cell line as an indicator of general cytotoxicity. The selectivity indices (SI) - the ratio of VERO $\mathrm{IC}_{50}$ to $\mathrm{D} 6$ or $\mathrm{W} 2 \mathrm{IC}_{50}$ - are calculated. All $\mathrm{IC}_{50} \mathrm{~S}$ are calculated using the XLFit fit curve fitting software. The antimalarial drug controls chloroquine and artemisinin are used as positive controls

\subsection{Antileishmanial assay}

The anti-leishmanial screen (LEM) tests samples for their ability to inhibit Leishmania donovani, a fly-borne protozoan that causes visceral leishmaniasis. Crude extracts are initially tested in a Primary Screen.

Primary Screen; at $80 \mu \mathrm{g} / \mathrm{mL}$ in duplicate and percent inhibitions (\% inh.) are calculated relative to negative and positive controls. Extracts showing $\geq 50 \%$ inhibition proceed to the secondary assay (Abdel-Mageed et al., 2012).

\subsection{Antimicrobial screen}

Crude extracts tested for antimicrobial activity against 90906, Methicillinresistant Staphylococcus aureus (MRSA) ATCC 33591, Staphylococcus aureus ATCC 2921, Escherichia coli ATCC 35218, Pseudomonas aeruginosa ATCC 27853, Mycobacterium intracellulare ATCC 23068 Candida albicans ATCC 90028, Candida glabrata ATCC90030, Candida krusei ATCC 6258, Aspergillus fumigates ATCC and Cryptococcus neoformans ATCC 90113, Ciprofloxacin and Amphotericin B were used as positive standards.

\section{Primary Screen;}

Crude extracts are initially tested at $50 \mu \mathrm{g} / \mathrm{mL}$ in duplicate and percent inhibitions (\% inh.) are calculated relative to negative and positive controls. Extracts showing $\geq 50 \%$ inhibition proceed to the Secondary Assay.

\section{Secondary Assay;}

In the Secondary Assay, samples dissolved to $20 \mathrm{mg} / \mathrm{mL}$ (crude extracts and some column fractions) are tested at $200,40,8 \mu \mathrm{g} / \mathrm{mL}$ and $\mathrm{IC}_{50} \mathrm{~s}$ vs. all 10 microbial strains are reported. Samples dissolved to $2 \mathrm{mg} / \mathrm{mL}$ (pure compounds and some column fractions) are tested at $20,4,0.8 \mu \mathrm{g} / \mathrm{mL}$ and $\mathrm{IC}_{50} \mathrm{~s}$ vs. all 10 microbial strains are reported. Pure compounds that have an $\mathrm{IC}_{50}$ of $\leq 7 \mu \mathrm{g} / \mathrm{mL}$ in the Secondary OI assay proceed to the Tertiary Assay.

The MIC is the lowest test concentration (in $\mu \mathrm{g} / \mathrm{mL}$ ) that inhibits the organism $100 \%$. The MFC or MBC is the lowest test concentration (in $\mu \mathrm{g} / \mathrm{mL}$ ) that kills the organism. While a pure compound may have an MIC, the cells may still be alive, just not growing. The MFC and MBC is a way to monitor the "cidality" or the killing ability of the test sample. All $\mathrm{IC}_{50} \mathrm{~S}$ are calculated using the XLFit fit curve fitting software. 


\subsection{Anti-inflammatory assays}

Anti-inflammatory activity was determined in terms of the inhibition of NF- $\kappa \mathrm{B}$ mediated transcription and inhibition of intracellular generation of reactive oxygen species (ROS) and nitric oxide (NO). Inhibition of NF- $\kappa \mathrm{B}$ mediated transcription was determined in human chondrosarcoma (SW1353) cells by a reporter gene assay as described earlier(Ma et al., 2007). Sp-1 was used as a control transcription factor to evaluate the toxicity of tested compounds in the same assay. Parthenolide was used as the positive control. Inhibition of intracellular NO production as a result of iNOS activity was assayed in mouse macrophages (RAW 264.7 cells) as described before (Quang et al., 2006). Parthenolide was included in each assay as the positive control. Inhibition of intracellular ROS generation (antioxidant activity) was assayed in human promyelocytic leukemia (HL-60) cells by using DCFH-DA as described previously (Reddy et al., 2007). Trolox was used as a positive control.

\subsection{Antioxidant assay}

Antioxidant activity was determined by the DCFH-DA (20,70-dichlorofluorescein diacetate) method in myelomonocytic HL-60 cells as described

earlier(Abbas et al., 2007). Briefly, for the assay, cells were plated at a density of 1.25105 cells per well in 96-well plates. After treatment with different concentrations of the test samples for $30 \mathrm{~min}$, cells were stimulated with $100 \mathrm{ng} \mathrm{mL} 1$ phorbol 12 myristate-13-acetate (PMA, Sigma) for $30 \mathrm{~min}$. DCFH-DA (molecular probes, 5mg mL1) was added and further Antimicrobial assay incubated for $15 \mathrm{~min}$. Plates were read on a polar star at an excitation wavelength of $485 \mathrm{~nm}$ and emission at $530 \mathrm{~nm}$ to measure the level of DCF production.

\subsection{Opioid and Cannabinoid Receptor Binding Assay}

This assay is designed to use a series of controls to determine the binding affinity of the test extracts against Kappa $(\kappa)$, Delta $(\delta)$ and $\mathrm{Mu}(\mu)$ opioid receptors in addition to Cannabinoid Receptors CB 1 and CB 2. 10uM of a positive control [norBinaltorphimine dihydrochloride $(\kappa)$, DPDPE $(\delta)$, or DAMGO $(\mu)$ ] was used to ascertain non-specific binding (NSB) and 1\% ethanol or DMSO in Tris-EDTA buffer was used to ascertain total binding. For Cannabinoid Receptor Binding Assay 10uM of a CP-55,940 was used to ascertain non-specific binding and $1 \%$ ethanol or DMSO in Tris-EDTA buffer was used to ascertain total binding. To eliminate the possibility of contamination in the test extracts, controls or the radioligand, wells with $1 \%$ ethanol or DMSO with no membrane were tested. The test have been done using a 96-well format as described in the scientific literature (Bradford, 1976; Kumarihamy et al., 2015).

\section{Results}

\subsection{Isolation and identification of the endophytic fungi}

In this study, a total of four endophytic fungal isolates were isolated on PDA from 20 seed segments of Nigella sativa (Ranunculaceae) seeds growing in Egypt and identified as Aspergillus tubingensis, Aspergillus parasiticus, Alternaria pluriseptata and Eurotium pseudoglaucus (Fig. 1). Morphological and microscopical characters of 
the identified fungi have been summarized in Table 1. The fungal identification was carried out by the regional center for mycology and biotechnology, (Cairo, Egypt). The fungi were grown on Asian rice as a solid media and then extracted with ethyl acetate. All fungal extracts were biologically screened for antileukemic, cytotoxic, antimalarial, antileishmanial, antimicrobial, antioxidant and anti-inflammatory activities as well as for cannabinoid and opioid receptor binding affinity.

Table 1: Morphological and microscopical characters of the identified fungi

\begin{tabular}{|c|c|c|}
\hline & Culture Examination & Microscopic Examination \\
\hline $\begin{array}{l}\text { Alternaria } \\
\text { pluriseptata }\end{array}$ & $\begin{array}{l}\text { Colonies on PDA grow rapidly, effuse, black, } \\
\text { reaching } 3-5 \mathrm{~cm} \text { diameters in two days at } 25^{\circ} \mathrm{C} \text {, } \\
\text { Reverse is black. }\end{array}$ & $\begin{array}{l}\text { Conidiophores } 4.3 \mu \mathrm{m} \text { thick. Conidia obclavate, golden } \\
\text { brown in colour, smooth } 32.0 \mathrm{X} 15.5 \mu \mathrm{m} \text {, with a short, } \\
\text { pale beak } 4.0 \mu \mathrm{m} \text { thick, with } 2-7 \text { transverse septa. }\end{array}$ \\
\hline $\begin{array}{l}\text { Aspergillus } \\
\text { parasiticus }\end{array}$ & $\begin{array}{l}\text { Colonies fast-growing, reaching } 5-7 \mathrm{~cm} \\
\text { diameters in four days at } 25^{\circ} \mathrm{C} \text { on malt media; } \\
\text { usually consist of a dense felt of yellowish } \\
\text { green mycelia, with pale yellow reverse. }\end{array}$ & $\begin{array}{l}\text { Conidiophores are coarsely roughened, geenish yellow } \\
\text { in colour, } 10.4 \mu \mathrm{m} \text {. Conidia globose, } 3.5 \mu \mathrm{m} \text {. } \\
\text { Chlamydospore was absent. Vesicles; subglobose, } 24.5 \\
\mu \mathrm{m} \text {. Sterigmata; one series }\end{array}$ \\
\hline $\begin{array}{l}\text { Aspergillus } \\
\text { tubingensis }\end{array}$ & $\begin{array}{l}\text { Colonies fast-growing, reaching } 4-5 \mathrm{~cm} \\
\text { diameters in four days at } 25^{\circ} \mathrm{C} \text { on malt media; } \\
\text { usually consist of a compact white basal } \\
\text { mycelium with black conidial heads. Reverse is } \\
\text { colorless }\end{array}$ & $\begin{array}{l}\text { Conidiophores; } 15.8 \mu \mathrm{m} \text {. Conidial heads; Globose to } \\
\text { radiate, mostly } 200-300 \mu \mathrm{m} \text {. Conidia globose, } 3.1 \mu \mathrm{m} \text {. } \\
\text { Chlamydospore was absent. Vesicles; globose, } 35.7 \mu \mathrm{m} \text {. } \\
\text { Sterigmata in two series }\end{array}$ \\
\hline $\begin{array}{l}\text { Eurotium } \\
\text { pseudoglaucus }\end{array}$ & $\begin{array}{l}\text { Colonies on PDA restricted in growth, yellow- } \\
\text { orange to brown, reverse, orange in center and } \\
\text { lighter toward in margin. }\end{array}$ & $\begin{array}{l}\text { Conidiophores } 5.3 \mu \mathrm{m} \text {. Conidia subglobose } 6.0 \mu \mathrm{m} \\
\text { Chlamydospore was absent. Vesicles; } 14.0 \mu \mathrm{m} . \\
\text { Sterigmata; one series. Cleistothecia; Abundant, } \\
\text { spherical. Asci; } 11 \mu \mathrm{m} \text { contain ascospores. }\end{array}$ \\
\hline
\end{tabular}

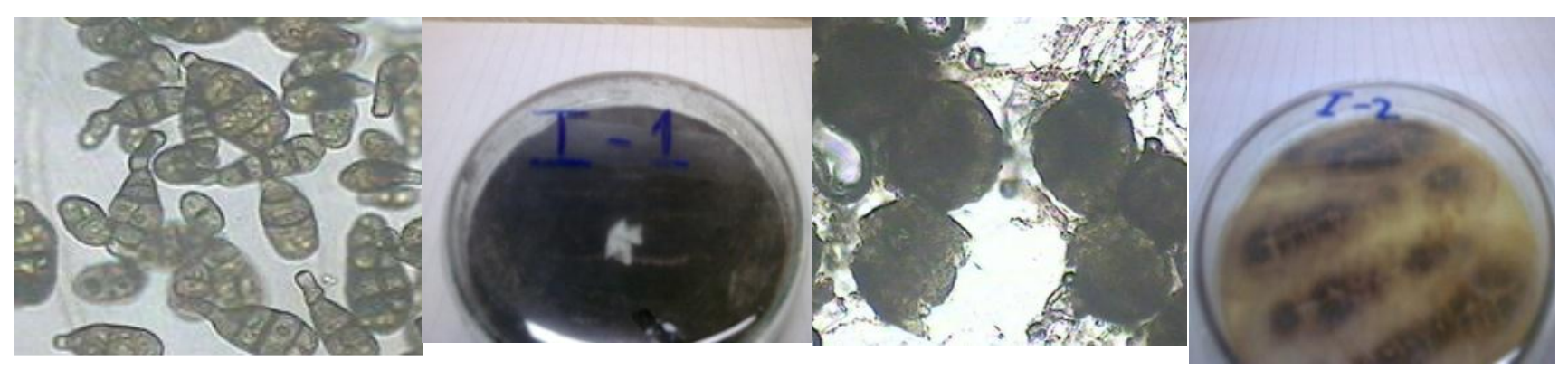

Alternaria pluriseptata

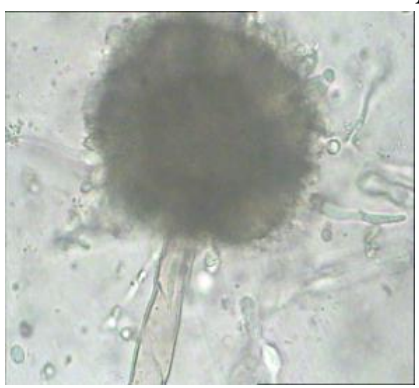

Aspergillus tubingensis

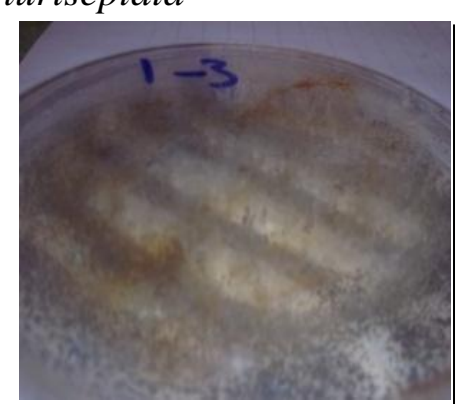

Eurotium pseudoglaucus

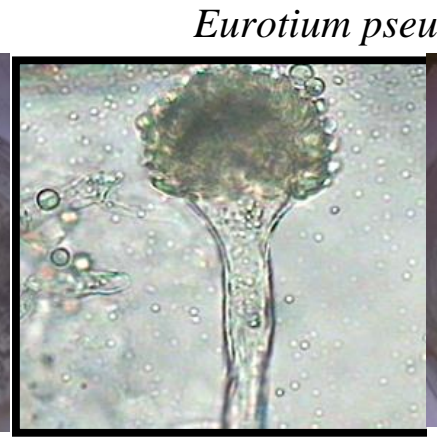

Aspergillus parasiticus

Figure 1. The isolated fungi under a microscope and as pure strains on malt agar plate 3.2. Antileukemic and cytotoxic assay results

Alternaria pluriseptata, Aspergellus parasiticus, Aspergillus tubingensis and Eurotium pseudoglaucus extracts showed good antileukemic activities against K562 
cells with $\mathrm{IC}_{50}$ values of 3.5, 0.4, 0.8 and $0.05 \mu \mathrm{g} / \mathrm{ml}$ and against HL60 cells with $\mathrm{IC}_{50}$ values of $0.2,0.16,0.7$ and $0.025 \mu \mathrm{g} / \mathrm{ml}$, respectively. These fungi have been chosen for cytotoxic activity examination against HepG2 (human hepatocarcinoma), Vero (African green monkey kidney fibroblasts) and LLC-PK1 (pig kidney epithelial). The endophytic fungal extracts of Alternaria pluriseptata and Aspergillus tubingensis showed moderate cytotoxic activity against LLC-PK 11 with $\mathrm{IC}_{50}$ values of 66 and 20 $\mu \mathrm{g} / \mathrm{ml}$, respectively as shown in Table 2 and fig. 2 .

Table 2: Antileukemic and cytotoxic activities result for the isolated endophytic fungi

\begin{tabular}{|c|c|c|c|c|c|}
\hline & \multicolumn{5}{|c|}{$\mathrm{IC}_{50} \mu \mathrm{g} / \mathrm{ml}$} \\
\hline & $\begin{array}{l}\text { K562 } \\
\text { cells }\end{array}$ & HL60 cells & HepG2 cells & Vero cells & $\begin{array}{l}\text { LLC-PK1 } \\
\text { cells }\end{array}$ \\
\hline Alternaria & 3.5 & 0.2 & & & \\
\hline pluriseptata & & & NA & NA & 66 \\
\hline Aspergellus & 0.4 & 0.16 & & & \\
\hline parasiticus & & & NA & NA & $\mathrm{NC}$ \\
\hline Aspergillus & 0.8 & 0.7 & & & \\
\hline tubingensis & & & NA & NA & 20 \\
\hline Eurotium & 0.05 & 0.025 & & & \\
\hline pseudoglaucus & & & NA & NA & NA \\
\hline
\end{tabular}

${ }^{\mathrm{a}} \mathrm{NA}$ : Extracts having $\mathrm{IC}_{50}$ value $>100 \mu \mathrm{g} / \mathrm{ml}$

\section{Antileukemic (IC50 $\mathrm{gg} / \mathrm{ml}$ ) assay results for the isolated endophytic fungi}
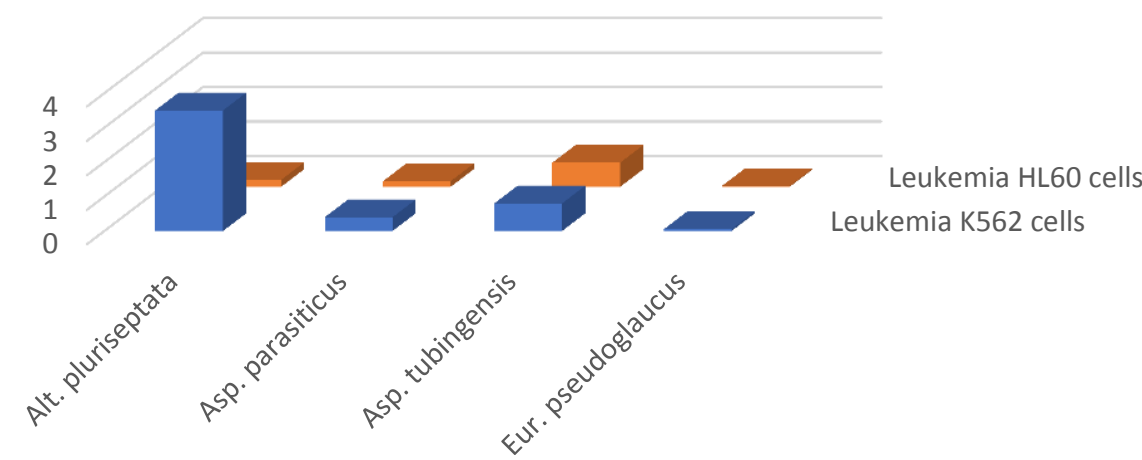

- Leukemia K562 cells a Leukemia HL60 cells

Fig. 2. Antileukemic result for the isolated endophytic fungi

3.3. Antimalarial assay results

The extract of Alternaria pluriseptata and Eurotium pseudoglaucus showed antimalarial activities against Plasmodium falciparum D6 clone with $\mathrm{IC}_{50}$ values of 12 and $8 \mu \mathrm{g} / \mathrm{mL}$ and against $\mathrm{W} 2$ clone with $\mathrm{IC}_{50}$ values of 14 and $8 \mu \mathrm{g} / \mathrm{mL}$, respectively as shown in Table 3.

Table 3: Antimalarial activity results for the isolated endophytic fungi 


\begin{tabular}{|c|c|c|}
\hline & $\begin{array}{l}\text { P. falciparum D6 } \mathrm{IC}_{50} \\
\mu \mathrm{g} / \mathrm{ml}\end{array}$ & $\begin{array}{l}\text { P. falciparum W2 } \mathrm{IC}_{50} \\
\mu \mathrm{g} / \mathrm{ml}\end{array}$ \\
\hline Alternaria pluriseptata & 12 & 14 \\
\hline Aspergellus parasiticus & NA & NA \\
\hline Aspergillus tubingensis & NA & NA \\
\hline Eurotium pseudoglaucus & 8 & 8 \\
\hline
\end{tabular}

${ }^{\text {a }} \mathrm{NA}$ : Extracts having $\mathrm{IC}_{50}$ value $>25.8 \mu \mathrm{g} / \mathrm{ml}$

3.4. Antileishmanial assay results

All fungal extracts of Alternaria pluriseptata, Aspergillus parasiticus, Aspergillus tubingensis and Eurotium pseudoglaucus inhibited the growth of $L$. donovani growth with \% Inhibition of 48.8, 5.6, 11.9, 7.6 and 49.8 respectively.

Table 4: Antileishmanial assay results

\begin{tabular}{lll}
\hline & \multicolumn{2}{l}{ L. donovani } \\
\cline { 2 - 3 } & $\% \mathrm{Inh}$. & $\mathrm{IC}_{50} \mu \mathrm{g} / \mathrm{ml}$ \\
\hline Alternaria pluriseptata & 48.8 & - \\
Aspergillus parasiticus & 5.6 & - \\
Aspergillus tubingensis & 7.6 & - \\
Eurotium pseudoglaucus & 49.8 & - \\
\hline
\end{tabular}

${ }^{\mathrm{a}} \mathrm{NA}$ : Extracts having $\mathrm{IC}_{50}$ value $>80 \mu \mathrm{g} / \mathrm{ml}$

3.5. Antimicrobial assay results

All endophytic fungal extracts have been examined for their ability to inhibit a panel of 5 bacteria and 5 fungi those are pathogenic to humans including; Staphylococcus aureus, Methicillin-resistant Staphylococcus aureus (MRSA), Escherichia coli, Pseudomonas aeruginosa, Mycobacterium intracellulare, Candida albicans, Candida glabrata, Candida krusei, Aspergillus fumigates and Cryptococcus neoformans. Some extracts exhibited inhibitory effects with different percentages against the examined organisms ranging from 1 to 34 (Table 5 and 6).

Table 5: Antibacterial assay results

\begin{tabular}{|c|c|c|c|c|c|c|c|c|c|c|}
\hline & \multicolumn{2}{|c|}{ S. aureus } & \multicolumn{2}{|c|}{$M R S$} & \multicolumn{2}{|c|}{ E. coli } & \multicolumn{2}{|c|}{$P$. aeruginosa } & \multicolumn{2}{|c|}{ M.Intracellulare } \\
\hline & $\%$ Inh. & $\mathrm{IC}_{50}$ & $\%$ Inh. & $\mathrm{IC}_{50}$ & $\%$ Inh. & $\mathrm{IC}_{50}$ & $\%$ Inh. & $\mathrm{IC}_{50}$ & $\%$ Inh. & $\mathrm{IC}_{50}$ \\
\hline $\begin{array}{c}\text { Alternaria } \\
\text { pluriseptata }\end{array}$ & 9 & - & 5 & - & 4 & - & 2 & - & 2 & - \\
\hline $\begin{array}{l}\text { Aspergillus } \\
\text { parasiticus }\end{array}$ & 5 & - & & - & 6 & - & 2 & - & - & - \\
\hline $\begin{array}{l}\text { Aspergillus } \\
\text { tubingensis }\end{array}$ & 3 & - & 2 & - & 17 & - & 4 & - & - & - \\
\hline $\begin{array}{c}\text { Eurotium } \\
\text { pseudoglaucus }\end{array}$ & 14 & - & 21 & - & 17 & - & - & - & - & - \\
\hline
\end{tabular}


Table 6: Antifungal assay results

\begin{tabular}{ccccccccccc} 
& \multicolumn{2}{c}{ C. albicans } & \multicolumn{2}{c}{ C. glabrata } & \multicolumn{2}{c}{ C. krusei } & A. fumigatus & C. neoformans \\
\cline { 2 - 9 } & $\%$ Inh. & IC $_{50}$ & $\%$ Inh. & IC $_{50}$ & $\%$ Inh. & IC $_{50}$ & $\%$ Inh. & IC $_{50}$ & $\%$ Inh. & IC $_{50}$ \\
\hline $\begin{array}{c}\text { Alternaria } \\
\text { pluriseptata }\end{array}$ & 8 & - & 4 & - & 27 & - & 7 & - & 7 & - \\
\hline $\begin{array}{c}\text { Aspergillus } \\
\text { parasiticus }\end{array}$ & 1 & - & 3 & - & 2 & - & 8 & - & & - \\
\hline $\begin{array}{c}\text { Aspergillus } \\
\text { tubingensis }\end{array}$ & 6 & - & 6 & - & 30 & - & 10 & - & 9 \\
\hline $\begin{array}{c}\text { Eurotium } \\
\text { pseudoglaucus }\end{array}$ & 10 & - & 3 & - & 34 & - & 4 & - & 21 \\
\end{tabular}

Anti-inflammatory activity assay results $\mathrm{IC}_{50} \mu \mathrm{g} / \mathrm{ml}$

\begin{tabular}{cccc}
\hline & $i N O S$ & $N F-k B$ & $S P-1$ \\
\hline Alternaria pluriseptata & 100 & $N A$ & $N A$ \\
\hline Aspergellus parasiticus & $N A$ & $N A$ & $N A$ \\
\hline Aspergillus tubingensis & 92 & $N A$ & $N A$ \\
\hline Eurotium pseudoglaucus & $N A$ & $N A$ & $N A$
\end{tabular}

3.6. Anti-inflammatory assay results

All the fungal extracts have been subjected to screen anti-inflammatory activities. The activity was determined in terms of the inhibition of nuclear factor (NF- $\kappa \mathrm{B})$ mediated transcription and inhibition of intracellular generation of reactive oxygen species (ROS) and nitric oxide synthase (NOS). The endophytic fungal extracts of Alternaria pluriseptata and Aspergillus tubingensis showed nitric oxide synthase inhibitory (iNOS) activities with $\mathrm{IC}_{50}$ values of 100 and $92 \mu \mathrm{g} / \mathrm{ml}$, respectively, as shown in Table 7 .

Table 7: Anti-inflammatory assay results

${ }^{\text {a }} \mathrm{NA}$ : Extracts having $\mathrm{IC}_{50}$ value $>100 \mu \mathrm{g} / \mathrm{ml}$

3.7. Anti-oxidant assay results

Anti-oxidant activities were determined by the DCFH-DA (20,70-dichlorofluorescein diacetate) method in myelomonocytic HL-60 cells. The endophytic fungal extracts of Alternaria pluriseptata, Aspergillus tubingensis and Eurotium pseudoglaucus showed anti-oxidant activities with $\mathrm{IC}_{50}$ values of 19,8 and $18 \mu \mathrm{g} / \mathrm{ml}$, respectively.

Table 8: Anti-oxidant assay results

\begin{tabular}{|c|c|}
\hline & Antioxidant activity $\quad \mathrm{IC}_{50} \mu \mathrm{g} / \mathrm{ml}$ \\
\hline Alternaria pluriseptata & 19 \\
\hline Aspergellus parasiticus & $N A$ \\
\hline Aspergillus tubingensis & 8 \\
\hline Eurotium pseudoglaucus & 18 \\
\hline
\end{tabular}

a $\mathrm{NA}$ : Extracts having $\mathrm{IC}_{50}$ value $>100 \mu \mathrm{g} / \mathrm{ml}$

3.8: Opioid receptors binding assay results 
The extracts of Alternaria pluriseptata, Aspergillus tubingensis and Eurotium pseudoglaucus exhibited very weak opioid receptors binding affinities against Delta receptors with \% inhibition values of $0.62,4.89$ and 9.17 and against $\mathrm{Mu}$ receptors \% inhibition values of 1.27, 14.82 and 11.87, respectively Aspergillus tubingensis extract weakly inhibited Kappa receptors with a value of $11.01 \%$.

Table. 9: Opioid receptors binding assay results

\begin{tabular}{ccc}
$\begin{array}{c}\text { Kappa receptors } \\
\text { \%Inh. }\end{array}$ & $\begin{array}{c}\text { Delta receptors } \% \\
\text { Inh. }\end{array}$ & $\begin{array}{c}\text { Mu receptors } \\
\% \text { Inh. }\end{array}$ \\
\hline- & 0.62 & 1.27 \\
\hline- & - & - \\
\hline 11.01 & 4.89 & 14.82 \\
\hline- & 9.17 & 11.87
\end{tabular}

3.9. Cannabinoid receptors binding assay results

Alternaria pluriseptata, Aspergillus tubingensis and Eurotium pseudoglaucus extracts were found to have weak inhibitory effects against CB 2 receptors with \% inhibition of $6.29,8.69$ and 14.88 , respectively.

Table 10: Cannabinoid receptors binding assay results

\begin{tabular}{lcc}
\hline & CB 1 receptors \%Inh & CB 2 receptors \% Inh \\
\hline Alternaria pluriseptata & - & 6.29 \\
\hline Aspergellus parasiticus & - & - \\
\hline Aspergillus tubingensis & - & 8.69 \\
\hline Eurotium pseudoglaucus & - & 14.88 \\
\hline
\end{tabular}

Acknowledgments: We are grateful to the Egyptian Government and National Center for Natural Products Research, School of Pharmacy, University of Mississippi, for financial support. We are also thankful to Drs. Melissa Jacob and Babu Tekwani for antimicrobial and antileishmanial assays. This investigation was conducted in part in a facility constructed with support from the research facilities improvement program C06 RR-14503-01 from the NIH NCRR. This work is supported in part by United States Department of Agriculture ARS Specific Cooperative Agreement No. 58-6408-2-0009

Conflicts of Interest: The authors declare no conflict of interest. REFERENCES

Abbas, F.A., Al-Massarany, S.M., Khan, S., Al-Howiriny, T.A., Mossa, J.S., Abourashed, E.A., 2007. Phytochemical and biological studies on Saudi Commiphora opobalsamum L. Natural Product Research 21(5), 383-391.

Abdel-Mageed, W.M., Backheet, E.Y., Khalifa, A.A., Ibraheim, Z.Z., Ross, S.A., 2012. Antiparasitic antioxidant phenylpropanoids and iridoid glycosides from Tecoma mollis. Fitoterapia 83(3), 500-507.

Bharate, S.B., Khan, S.I., Yunus, N.A.M., Chauthe, S.K., Jacob, M.R., Tekwani, B.L., Khan, I.A., Singh, I.P., 2007. Antiprotozoal and antimicrobial activities 
of O-alkylated and formylated acylphloroglucinols. Bioorganic \& Medicinal Chemistry 15(1), 87-96.

Bilal, S., Ali, L., Khan, A.L., Shahzad, R., Asaf, S., Imran, M., Kang, S.-M., Kim, S.-K., Lee, I.-J., 2018. Endophytic fungus Paecilomyces formosus LHL10 produces sester-terpenoid YW3548 and cyclic peptide that inhibit urease and $\alpha$-glucosidase enzyme activities. Archives of microbiology, 1-10.

Bradford, M.M., 1976. A rapid and sensitive method for the quantitation of microgram quantities of protein utilizing the principle of protein-dye binding. Analytical biochemistry 72(1), 248-254.

Chagas, F.O., Dias, L.G., Pupo, M.T., 2016. New perylenequinone derivatives from the endophytic fungus Alternaria tenuissima SS77. Tetrahedron letters 57(29), 3185-3189.

Chandra, S., 2012. Endophytic fungi: novel sources of anticancer lead molecules. Applied microbiology and biotechnology 95(1), 47-59.

Das, M., Prakash, H.S., Nalini, M.S., 2018. Bioactive sesquiterpene, plasticizer, and phenols from the fungal endophytes of Polygonum chinense L. Annals of Microbiology 68(10), 595-609.

Deshmukh, S.K., Mishra, P.D., Kulkarni-Almeida, A., Verekar, S., Sahoo, M.R., Periyasamy, G., Goswami, H., Khanna, A., Balakrishnan, A., Vishwakarma, R., 2009. Anti-inflammatory and anticancer activity of ergoflavin isolated from an endophytic fungus. Chemistry \& biodiversity 6(5), 784-789.

EImi, A., West, C., 1995. Endophyte infection effects on stomatal conductance, osmotic adjustment and drought recovery of tall fescue. New Phytologist 131(1), 61-67.

Fisher, F.W., Cook, N.B., 1998. Fundamentals of diagnostic mycology. WB Saunders Philadelphia, PA.

Gao, F.-k., Dai, C.-c., Liu, X.-z., 2010. Mechanisms of fungal endophytes in plant protection against pathogens. African Journal of Microbiology Research 4(13), 1346-1351.

Guo, F., Li, Z., Xu, X., Wang, K., Shao, M., Zhao, F., Wang, H., Hua, H., Pei, Y., Bai, J., 2016. Butenolide derivatives from the plant endophytic fungus Aspergillus terreus. Fitoterapia 113, 44-50.

Hoog, G.d., Guarro, J., Gené, J., Figueras, M., 2000. Atlas of clinical fungi. Centraalbureau voor Schimmelcultures (CBS).

Huang, W.-Y., Cai, Y.-Z., Xing, J., Corke, H., Sun, M., 2007. A potential antioxidant resource: endophytic fungi from medicinal plants. Economic Botany 61(1), 14.

Hussain, H., Krohn, K., Draeger, S., Meier, K., Schulz, B., 2009. Bioactive chemical constituents of a sterile endophytic fungus from Meliotus dentatus. Records of Natural Products 3(2). 
Jalgaonwala, R.E., Mohite, B.V., Mahajan, R.T., 2017. A review: natural products from plant associated endophytic fungi. Journal of microbiology and biotechnology research 1(2), 21-32.

Kumar, S., Kaushik, N., 2012. Metabolites of endophytic fungi as novel source of biofungicide: a review. Phytochemistry reviews 11(4), 507-522.

Kumarihamy, M., Leon, F., Pettaway, S., Wilson, L., Lambert, J., Wang, M., Hill, C.M., Mccurdy, C.R., Elsohly, M.A., Cutler, S.J., 2015. In vitro opioid receptor affinity and in vivo behavioral studies of Nelumbo nucifera flower. Journal of Ethnopharmacology 174, 57-65.

Li, H.-L., Li, X.-M., Liu, H., Meng, L.-H., Wang, B.-G., 2016. Two new diphenylketones and a new xanthone from Talaromyces islandicus EN-501, an endophytic fungus derived from the marine red alga Laurencia okamurai. Marine drugs 14(12), 223.

Li, S., Li, Z., Qian, L., Xiao-Wen, L., Ju-Qun, X., Gui-Mei, K., Yong-Chun, S., 2015. Fumigaclavine I, a new alkaloid isolated from endophyte Aspergillus terreus. Chinese journal of natural medicines 13(12), 937-941.

Ma, G., Khan, S.I., Benavides, G., Schühly, W., Fischer, N.H., Khan, I.A., Pasco, D.S., 2007. Inhibition of $\mathrm{NF}-\kappa \mathrm{B}-$ mediated transcription and induction of apoptosis by melampolides and repandolides. Cancer chemotherapy and pharmacology 60(1), 35-43.

Márquez, L.M., Redman, R.S., Rodriguez, R.J., Roossinck, M.J., 2007. A virus in a fungus in a plant: three-way symbiosis required for thermal tolerance. science 315(5811), 513-515.

Metwaly, A., Kadry, H., El-Hela, A., Elsalam, A., Ross, S., 2014. New antimalarial benzopyran derivatives from the endophytic fungus Alternaria phragmospora. Planta Medica 80(10), PC11.

Metwaly, A., Kadry, H., El-Hela, A., Mohammad, A., Ma, G., Cutler, S., Ross, S., 2013. Antileukemic, antileishmanial and antifungal activities of secondary metabolites from the endophytic fungus Nigrospora sphaerica. Planta Medica 79(05), P52.

Metwaly, A.M., Fronczek, F.R., Ma, G., Kadry, H.A., Atef, A., Mohammad, A.E.I., Cutler, S.J., Ross, S.A., 2014a. Antileukemic $\alpha$-pyrone derivatives from the endophytic fungus Alternaria phragmospora. Tetrahedron letters 55(24), 3478-3481.

Metwaly, A.M., Ghoneim, M.M., Musa, A., 2015. Two new antileishmanial diketopiperazine alkaloids from the endophytic fungus Trichosporum sp. Derpharmachemica 7, 322-327.

Metwaly, A.M., Kadry, H.A., Atef, A., Mohammad, A.-E.I., Ma, G., Cutler, S.J., Ross, S.A., 2014b. Nigrosphaerin A a new isochromene derivative from the endophytic fungus Nigrospora sphaerica. Phytochemistry letters 7, 1-5. 
Metwaly, A.M., Wanas, A.S., Radwan, M.M., Ross, S.A., ElSohly, M.A., 2017. New $\alpha$-Pyrone derivatives from the endophytic fungus Embellisia sp. Medicinal Chemistry Research 26(8), 1796-1800.

Mustafa, J., Khan, S.I., Ma, G., Walker, L.A., Khan, I.A., 2004. Synthesis and anticancer activities of fatty acid analogs of podophyllotoxin. Lipids 39(2), 167-172.

Orfali, R.S., Aly, A.H., Ebrahim, W., Proksch, P., 2015. Isochroman and isocoumarin derivatives from hypersaline lake sediment-derived fungus Penicillium sp. Phytochemistry letters 13, 234-238.

Petrini, O., 1991. Fungal endophytes of tree leaves, Microbial ecology of leaves. Springer, pp. 179-197.

Quang, D.N., Harinantenaina, L., Nishizawa, T., Hashimoto, T., Kohchi, C., Soma, G.-I., Asakawa, Y., 2006. Inhibition of nitric oxide production in RAW 264.7 cells by azaphilones from xylariaceous fungi. Biological and Pharmaceutical Bulletin 29(1), 34-37.

Reddy, M.K., Gupta, S.K., Jacob, M.R., Khan, S.I., Ferreira, D., 2007. Antioxidant, antimalarial and antimicrobial activities of tannin-rich fractions, ellagitannins and phenolic acids from Punica granatum L. Planta Medica 73(05), 461-467.

Roper, P.R., Drewinko, B., 1976. Comparison of in vitro methods to determine druginduced cell lethality. Cancer Research 36(7 Part 1), 2182-2188.

Schulz, B., Römmert, A.-K., Dammann, U., Aust, H.-J., Strack, D., 1999. The endophyte-host interaction: a balanced antagonism? Mycological Research 103(10), 1275-1283.

Stierle, A.A., Stierle, D.B., 2015. Bioactive secondary metabolites produced by the fungal endophytes of conifers. Natural Product Communications 10(10), 1671.

Tawfike, A.F., Abbott, G., Young, L., Edrada-Ebel, R., 2018. Metabolomic-guided isolation of bioactive natural products from Curvularia sp., an endophytic fungus of Terminalia laxiflora. Planta Medica 84(3), 182-190.

Tenguria, R.K., Khan, F.N., Quereshi, S., 2011. Endophytes - mines of pharmacological therapeutics. World J. Sci. Technol. 1(Copyright (C) 2013 American Chemical Society (ACS). All Rights Reserved.), 127-149.

Waller, F., Achatz, B., Baltruschat, H., Fodor, J., Becker, K., Fischer, M., Heier, T., Hückelhoven, R., Neumann, C., von Wettstein, D., 2005. The endophytic fungus Piriformospora indica reprograms barley to salt-stress tolerance, disease resistance, and higher yield. Proceedings of the National Academy of Sciences 102(38), 13386-13391.

Wiyakrutta, S., Sriubolmas, N., Panphut, W., Thongon, N., Danwisetkanjana, K., Ruangrungsi, N., Meevootisom, V., 2004. Endophytic fungi with antimicrobial, anti-cancer and anti-malarial activities isolated from Thai medicinal plants. World journal of microbiology and biotechnology 20(3), 265-272. 
Zheng, N., Yao, F., Liang, X., Liu, Q., Xu, W., Liang, Y., Liu, X., Li, J., Yang, R., 2018. A new phthalide from the endophytic fungus Xylaria sp. GDG-102. Natural product research 32(7), 755-760.

\section{التقييم البيولوجي المقارن لأربعة فطريات معزولة من بذور حبة البركة}

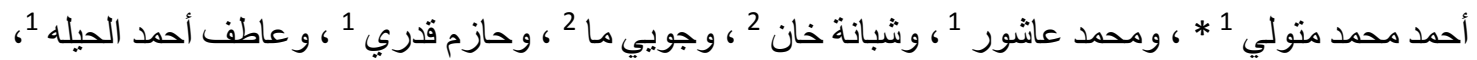

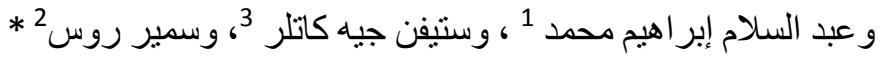

1- قسم العقاقير ، كلية الصبدلة ، جامعة الأزهر ، القاهرة ، مصر

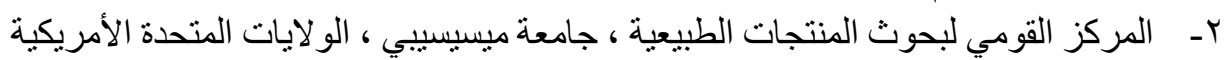

r- قسم الكيمياء الطبية ، كلية الصيدلة ، جامعة ميسيسيبي ، الولايات المتحدة الأمريكية

الخلاصة :في هذه الدر اسة ، تم عزل ما مجمو عه أربعة فطريات الفطرية من بذور نيجيلا ساتيفا التي تتمو في مصر .

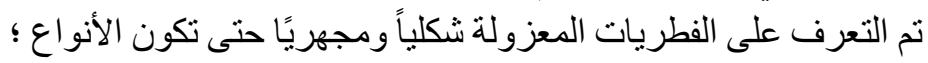

Eurotium و Aspergillus parasiticus و Aspergillus tubingensis و Alternaria pluriseptata

pseudoglaucus.

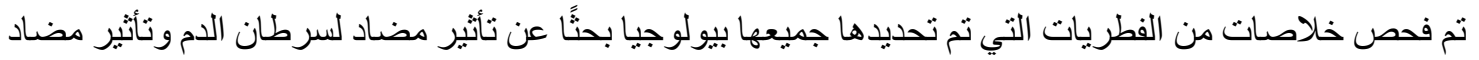
للخلايا السرطانية وتأثير مضاد للشمانيا وتأثير مضاد للملاريا وتأثير مضاد الميكروبات و تأثير مضادات الثات الأكسدة وتأثثير مضاد للالتهابات 